\title{
PENGARUH MODEL COOPERATIVE LEARNING TIPE TEAMS GAMES TOURNAMENT (TGT) TERHADAP KECERDASAN INTERPERSONAL PADA MATA PELAJARAN IPS
}

\author{
Marianti $^{2}, *$, Ratnawati Susanto ${ }^{2}$ \\ 1 Universitas Esa Ungggul \\ 2 Universitas Esa Ungggul
}

\begin{abstract}
Abstrak
Interpersonal intelligence is one of the goals in elementary school education. Interpersonal intelligence is a key element in the adaptation of children in their social relationships. SDN Kebon Jeruk 11 Pagi West Jakarta found a number of 19 students of 30 children (63\%) have barriers Interpersonal intelligence. Quantitative Research with One Shot Case Study Experiment using sample saturated with size 30 in research influence influence model cooperative learning type Teams Games Tournament (TGT) to interpersonal intelligence. The results of this study prove that: The more effective the steps of cooperative learning model type TGT done then the better the interpersonal intelligence. So in this research result that model Cooperative Learning type Teams Games Tournament (TGT) have positive effect to interpersonal intelligence.
\end{abstract}

\author{
Keywords: \\ Cooperative Learning \\ Model, Teams Games \\ Tournament (TGT) type, \\ Interpersonal \\ Intelligence.
}

\section{Pendahuluan}

Pendidikan merupakan modal yang sangat penting untuk dapat meningkat-kan dan mengembangkan kualitas sumber daya manusia. Pendidikan adalah usaha sadar dan terencana untuk mewujudkan suasana belajar dan proses pembelajaran agar peseta didik secara aktif mengembangkan potensi dirinya untuk memiliki kekuatan spiritual keagamaan, pengendalian diri, kepri-badian, kecerdasan, akhlak mulia serta keteram-pilan yang diperlukan dirinya, masyarakat, bangsa dan negara.Hal ini tercantum dalam Undang-Undang 1945 pasal $28 \mathrm{C}$ tentang hak asasi manusia ayat 1 yang berbunyi: "Setiap orang berhak mengembangkan diri melalui kebutuhan dasarnya, berhak men-dapatkan pendidikan dan memperoleh manfaat dari ilmu pengetahuan dan teknologi, seni dan budaya demi meningkatkan kualitas hidupnya dan demi kesejahteraan umat manusia"

Maka dari itu masyarakat Indonesia tentunya sangat meng-harapkan pendidikan yang lebih maju, pendidikan yang berorientasi ke masa depan.Salah satu tujuan dari pendidikan adalah mengembangkan kecerdasaan, bukan hanya sekedar mempelajari ilmu pe-ngetahuan. Kecerdasan adalah ke-mampuan untuk menyelesaikan masalah atau menciptakan sesuatu yang bernilai.

Pengembangan kecerdasan sese-orang individu tidak dapat dilepas-kan dari diri sendiri. Gardner (Chatib, 2015:49) mengungkapkan bahwa ter-dapat 8 karakterikstik kecerdasan salah satunya yaitu kecerdasan interpersonal. kecerdasan interpersonal tidak terlepas dari hubungannya dengan inidividu lainnya yang disebut kecerdasan interpersonal. Hal ini sejalan dengan kodrat hidup manusia sebagai makhluk sosial.

Kecerdasan interpersonal menjadi salah satu tujuan dalam pendidikan di tingkat Sekolah Dasar. Gardner (imanita,2015:47) menyatakan kecer-dasan interpersonal merupakan kecer-dasan dalam berinteraksi dengan orang lain, suka berdiskusi, sangat aktif, mampu memberikan motivasi dan dapat memahami perasaan orang lain.

Bagi anak, kecerdasan inter-personal sangat membantu dalam me-nyesuaikan diri serta dalam membentuk hubungan sosial.

Berdasarkan data yang diperoleh dari hasil observasi di SDN Kebon Jeruk 11 Pagi Jakarta Barat melalui catatan guru kelas IV ditemukan sejumlah 19 siswa dari 30 anak (63\%) memiliki per-masalahan atau hambatan dalam kecerdasan Interpersonal. Indi-kator yang terlihat sebagai permasalah-an dalam sikap atau hambatan dalam kecerdasan interpersonal terhadap ling-kungannya. Siswa memilih-milih 
teman dalam bergaul, berkelompok hanya dengan teman yang sama pada setiap waktu, tidak berani mengajukan pertanyaan, enggan menjawab per-tanyaan, tidak siap ketika harus menjelaskan atau memaparkan ide dan pendapatnya di muka kelas, tidak menanggapi jawaban dan pertanyaan teman dan masih terdapatnya siswa yang tidak membalas sapa temannya.

Data lain yang diperoleh dari dokumen Tata Usaha(TU) didapati bahwa pada tahun ajaran 2016/2017 ini terdapat kasus mutasi keluarnya siswa kelas IV sebanyak 2 anak dari 30 siswa (7\%) yang disebabkan karena alasan kurang nyamannya siswa dalam per-temanan atau pergaulan dengan siswa lainnya dan di dalam interaksi dengan guru. Hal ini juga menjadikan ke-prihatinan bahwa kecerdasan inter-personal siswa menjadi bagian dari permasalahan siswa di sekolah dalam proses pembelajaran.

Kecerdasaan interpersonal bagi anak diperkuat oleh pendapat Jasmine (2016:27) yang menyatakan bahwa kecerdasan interpersonal juga dapat dilihat dengan ekspresi rasa gembira saat berteman dan rasa senang dalam berbagai macam aktivitas sosial serta ketidaknyamanan atau keengganan dalam bergaul dan memilih untuk sendiri atau menyendiri.Hal tersebut sangat mempengaruhi proses berlang-sungnya pembelajaran seperti yang di ungkapkan said dan budimanjaya (2015:261) menyatakan bahwa siswa dengan kecerdasan interpersonal akan dapat memahami proses belajar meng-ajar dalam interaksinya dengan orang lain secara efektif. Kelas yang dipenuhi dengan siswa yang memiliki kecerdasan interpersonal, memungkinkan aktivitas pembelajaran dilakukan sebagai proses interaksi kerja sama dalam sebuah kelompok.

Namun sebaliknya, siswa yang kurang dalam kecerdasan inter-personalnya akan memiliki kecenderungan acuh tidak acuh, kurang mau bekerja sama dengan siswa lain, bersikap menyendiri, kurang mampu berinteraksi dengan siswa yang lain, maupun dengan warga sekolah lainnya.

Dari hasil wawancara dengan guru kelas IV di SDN 11 pagi Kebon Jeruk Jakarta Barat diidentifikasi berbagai faktor penyebab rendahnya kecerdasan interpersonal siswa, antara lain dalam ketidakperdulian orang tua dan guru dalam memberikan kesempatan bagi siswa dalam pengembangan kecerdasan interpersonal. Ketidakperdulian guru di dalam pengembangan kecerdasan inter-personal siswa dikontribusikan melalui cara guru didalam penggunaan metode ceramah sebagai metode konvensional. Metode ceramah yang digunakan guru menyebabkan interaksi satu arah yang berfokus pada keatikfan guru dan tidak memberikan kesempatan interaksi pada diri siswa, oleh karena itu guru seharusnya dapat menerapkan metode pembelajaran yang dapat melatih interaktif siswa guru mengembakan kecerdasan interpersonalnya. Salah satu model pembelajaran yang dapat meng-embangkan kecerdasan interpersonal siswa adalah model pembelajaran cooperative learning.

Kerangka dasar pemikiran diguna-kannya cooperative learning ini karena merupakan metode yang dapat mem-bantu siswa untuk menumbuhkan kepekaan dari kepedulian terhadap lingkungan dan sesama, dan me-numbuhkan kemampuan kerja sama, mengembakan sikap sosial, dan me-numbuhkan keterampilan.

Salah satu tipe model cooperative adalah teams games tournament (TGT) yang sangat menekankan pada pentingnya interaksi dalam tim. Pada model ini siswa memainkan permainan dengan anggotaanggota tim untuk memperoleh tambahan poin untuk skor tim mereka atau dilakukan turnamen mingguan dimana siswa memainkan game akademik dengan anggota tim lain untuk menyumbangkan poin bagi skor timnya. Peneliti memilih tipe TGT dibanding tipe lain karena dalam tipe TGT terdapat adanya game-game akademik, sehingga dapat menjadikan proses pembelajaran menjadi lebih menyenangkan dan dalam suasana gembira serta terciptanya kompetensi tim yang didasarkan pada tanggung jawab masing-masing individunya.

Hasil penelitian oleh Bastian (2013) yang menyatakan apabila model pembelajaran Teams Games Turnament (TGT) dipersiapkan secara matang dengan prosedur yang baik lebih tepat dibandingkan dengan metode ceramah yang cenderung mengakibatkan kebosanan dalam proses pembelajaran IPS mampu meningkatkan keaktifan siswa dalam belajar dikelas. Selain itu penelitian oleh Rohmah (2016) mengatakan pembelajaran kooperatif tipe TGT ini sistem penilaian dilakukan terhadap kelompok dengan memberikan reward (penghargaan) di akhir pembelajaran, jika kelompok tersebut mampu menunjukkan prestasi yang dipersyaratkan. Dengan demikian, setiap anggota kelompok akan mempunyai ketergantungan yang positif.

Kegiatan games di turnamen yang ada di tipe TGT sangat selaras dan efektif untuk pengembangan kecerdasan interpersonal. Salah satu mata pelajaran yang dapat digunakan sebagai cara strategis dalam pengembangan kecer-dasan interpersonal adalah mata pela-jaran IPS. Sejalan dengan pendapat yang diungkapkan (Hutami,2015:14) bahwa IPS adalah bidang studi yang merupakan paduan dari sejumlah mata pelajaran sosial yang berhubungan dengan sikap sosial yang erat kaitannya dengan kecerdasan interpersonal.

Berdasarkan hal tersebut maka peneliti menganggap perlu untuk melakukan penelitian dengan judul "Pengaruh Model Cooperative Learning tipe Teams Games Tournament (TGT)" terhadap kecerdasan 
interpersonal mata pelajaran IPS kelas IV SDSN 11 Pagi Kebon Jeruk Jakarta Barat. Tujuan penelitian ini adalah mengetahui apakah terdapat pengaruh model Cooperative Learning tipe Teams Games Tournament terhadap kecerdasan interpersonal mata pelajaran IPS kelas IV SDSN 11 Pagi Kebon Jeruk Jakarta Barat.

\section{Metode Penelitian}

Penelitian ini adalah penelitian kuantitatif dengan menggunakan pre-eksperimen dengan bentuk One Shot Case Study. Dengan design ini terdapat suatu kelompok diberi treatment/ perlakuan, dan selanjutnya diobservasi hasilnya. Treatment adalah sebagai variable indenpenden, dan hasil adalah sebagai variabel dependent (Sugiyono, $2011: 74$ )

Peneliti dalam melakukan penelitian initidak melakukan randominasi tetapi dengan menetapkan kelompok studi. Variabel dalam penelitian ini adalah cooperative learning tipe TGT sebagai variabe bebas (X) terhadap kecerdasan interpersonal sebagai variabel terikat (Y).

\section{0}

Keterangan:

$\mathrm{X}=$ Treatment yang diberikan ( Variabel Independent)

$\mathrm{O}=$ Observasi (Variabel Dependent)

Hipotesis penelitian ini adalah Diduga terdapat pengaruh yang positif Cooperative Learning Tipe Teams games Tournament (TGT) Terhadap Kecerdasan Interpersonal.

\section{Hipotesis Statistik: \\ Ho : $p y 1 \leq 0$ \\ $\mathrm{H} 1: \rho y 1 \geq 0$}

Keterangan :

Ho : Variabel cooperative learning tipe teams games Tournament $(\mathrm{X})$ tidak memilki pengaruh terhadap variable kecerdasan interpersonal (Y)

H1 : Variabel cooperative learning tipe teams games tournament (X) memiliki peng- aruh terhadap kecerdasan inter-personal (Y).

Populasi dalam penelitian ini adalah siswa-siswi kelas IVC SDSN 11 Kebon Jeruk Jakarta Barat Tahun pelajaran 2016/1017 yang berjumlah 30 orang. Dengan menggunakan sampel jenuh maka sampel diambil dari populasi dengan ukuran sampel 30 orang. Instrumen yang digunakan adalah angket dengan menggunakan skala Likert, dengan skala 5 opsi. Teknik pengolahan data dilakukan dengan analisa statistic parametric dengan bantuan Ms. Excell dan SPSS versi 23. Penyajian data penelitian menggunakan statistic deskriptif. Tahapan pengolahan data dilakukan dengan melakukan: a) Uji Analisis Instrumen Uji Coba dengan menggunakan rumus Korelasi Product Moment dan Alpha Cronbach, b) Uji Persyaratan Analisis dengan tahapan Persamaan Lineiritas dan Signifikansi, Uji Normalitas Data (Liliefors) dan Uji Homogenitas (Bartlett). Uji Hipotesis dengan menggunakan analisis korelasi (Product Moment) dan Uji t (Anova).

\section{Hasil Dan Pembahasan}

Skor data penelitian yang diperoleh melalui angket, disajikan pada Tabel 1 sebagai berikut,

Tabel 1. Statistik Deskriptif Data Penelitian

\section{Statistics}

\begin{tabular}{cc}
\hline Model Cooperative & Kecerdasan \\
Learning Tipe TGT & Interpersonal \\
\hline 30 & 30 \\
0 & 0 \\
78,47 & 110,33
\end{tabular}




\begin{tabular}{cc}
2,254 & 2,421 \\
77,50 & 110,00 \\
95 & 110 \\
12,345 & 13,260 \\
152,395 & 175,816 \\
40 & 58 \\
60 & 80 \\
100 & 138 \\
2354 & 3310 \\
\hline
\end{tabular}

Dari tabel 1 dapat dideskripsikan bahwa pada: (1) variabel Kecerdasan Interpersonal (Y) diperoleh data bahwa: dengan responden 30 diperoleh: nilai rata-rata berada pada skor 110,33, dengan median (nilai tengah) 110,00, dan modus (nilai yang paling sering muncul) 110, standar deviasi adalah 13,260, variamce 175,816 dengan ranger (jarak rentang) 58, nilai maksimum 138 dan nilai minimum 80 dengan jumlah total skor 3310.; dan (2) variabel Model Cooperative Learning tipe TGT (X) diperoleh data bahwa: dengan responden 30 diperoleh: nilai rata-rata berada pada skor 78,47, dengan median (nilai tengah) 77,50, dan modus (nilai yang paling sering muncul) 95, standar deviasi adalah 12,345, variance 152,395 dengan ranger (jarak rentang) 40, nilai maksimum 100 dan nilai minimum 80 dengan jumlah total skor 2354 .

Tabel 2. Distribusi Frekuensi Variabel Kecerdasan Interpersonal (Y)

\begin{tabular}{llll}
\hline INTERVAL KELAS & $\begin{array}{l}\text { FREKUENSI } \\
\text { ABSOLUT }\end{array}$ & RELATIF (\%) & KUMULATIF (\%) \\
\hline $80-89$ & 2 & 7 & 7 \\
$90-99$ & 3 & 10 & 17 \\
$100-109$ & 8 & 27 & 44 \\
$110-119$ & 10 & 33 & 77 \\
$120-129$ & 4 & 13 & 90 \\
$130-139$ & 3 & 10 & 100 \\
JUMLAH & 30 & 100 & \\
\hline
\end{tabular}

Dari tabel 2 Distribusi Frekuensi dapat dideskripsikan bahwa frekuensi absolut terbesar ada pada interval kelas 110 - 119 dengan jumlah absolut 10. Skor teoretik dari variabel kecerdasan interpersonal berada pada rentang 80 - 139. Sementara skor empirik 80 - 138. Data dapat ditunjukkan dengan histogram berikut.

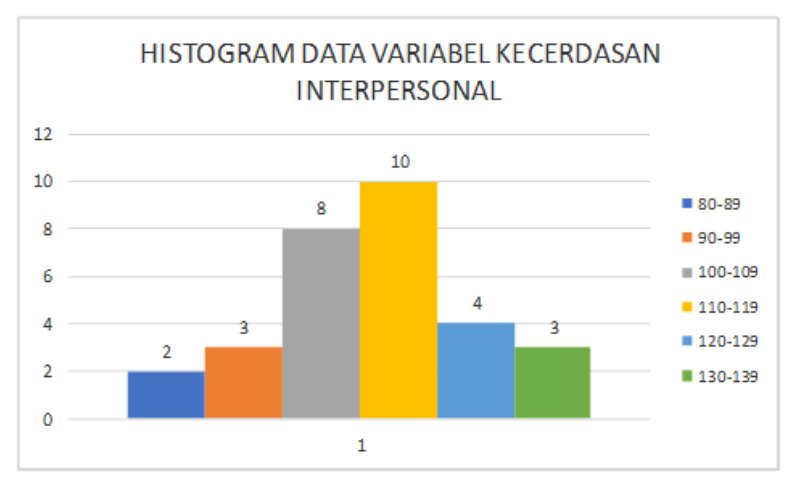

Gambar 1. Histogram Variabel Kecerdasan Interpersonal

Skor data penelitian untuk variabel Model Cooperative Learning Tipe TGT dapat ditunjukkan dengan tabel berikut. 
Tabel 3. Distribusi Frekuensi Variabel Cooperative Learning Tipe TGT

\begin{tabular}{llll}
\hline INTERVAL & FREKUENSI & & \\
KELAS & ABSOLUT & RELATIF (\%) & KUMULATIF (\%) \\
\hline $60-66$ & 6 & 20 & 20 \\
$67-73$ & 5 & 17 & 37 \\
$74-80$ & 6 & 20 & 57 \\
$81-87$ & 4 & 13 & 70 \\
$88-94$ & 4 & 13 & 83 \\
$95-101$ & 5 & 17 & 100 \\
JUMLAH & 30 & 100 & \\
\hline
\end{tabular}

Dari tabel 4 Distribusi frekuensi dapat dideskripsikan bahwa frekuensi absolut terbesar ada pada interval kelas 60-66 dan 74-80 dengan jumlah absolut 6. Skor teoretik dari variabel kecerdasan interpersonal berada pada rentang 20 - 100. Sementara skor empirik 60-100.

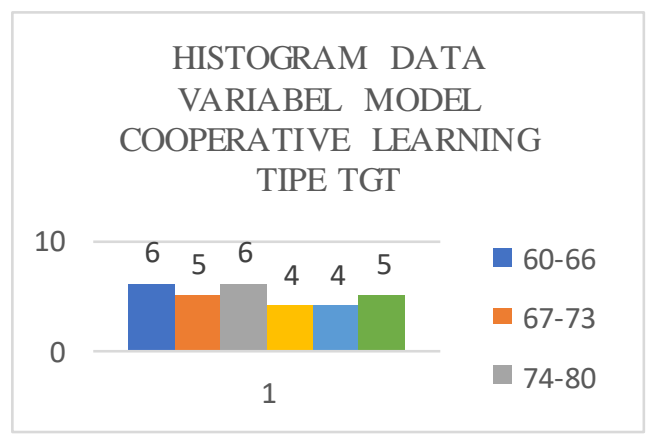

Gambar 2. Histogram Variabel Model Cooperative Learning Tipe TGT

Persamaan Regresi

\begin{tabular}{llllll}
\multicolumn{7}{c}{ Tabel 4 Persaman Regresi Y = a + bx } \\
Coefficients
\end{tabular}

a. Dependent Variable: Kecerdasan Interpersonal

Persamaan regresi yang diperoleh adalah: $\mathrm{Y}=\mathrm{a}+\mathrm{bX}$; dengan $\mathrm{a}=107,487$, dan $\mathrm{b}=0,036 ; \quad \mathrm{Y}=$ $107,487+0,036 X$. Dari persamaan regresi tersebut, dapat dinyatakan bahwa model ini dapat dipakai untuk persamaan dalam penelitian ini, dengan makna bahwa: Tanpa diberikan perlakuan X (model 
cooperative learning tipe TGT) maka kecerdasan interpersonal akan memiliki kontribusi sebesar 107,487 dan perlakuan satu satuan pada $\mathrm{X}$ akan meningkatkan kesiapan belajar $\left(\mathrm{Y}_{1}\right)$ sebesar 0,036.

Sebelum hasil perhitungan tersebut digunakan untuk prediksi, persamaan regresi harus memenuhi syarat keberartian dan linieritas persamaan regresi. Untuk mengetahui keberartian dan linieritas persamaan regresi dilakukan uji F yang dapat dilihat pada Tabel 5 sebagai berikut:

Tabel 5 Analisis Uji Keberartian dan Linieritas Persamaan Regresi $Y=a+b x$ ANOVA $^{\mathrm{a}}$

\begin{tabular}{|c|c|c|c|c|c|c|}
\hline Model & & $\begin{array}{l}\text { Sum of } \\
\text { Squares }\end{array}$ & Df & $\begin{array}{l}\text { Mean } \\
\text { Square }\end{array}$ & $\mathrm{F}$ & Sig. \\
\hline \multirow[t]{3}{*}{1} & Regressi & 5,817 & 1 & 5,817 & $\begin{array}{l}, 53 \\
2\end{array}$ & $\begin{array}{l}, 049 \\
\mathrm{~b}\end{array}$ \\
\hline & Residual & $\begin{array}{l}5092,85 \\
0\end{array}$ & 28 & $\begin{array}{l}181,88 \\
7\end{array}$ & & \\
\hline & Total & $\begin{array}{l}5098,66 \\
7\end{array}$ & 29 & & & \\
\hline
\end{tabular}

a. Dependent Variable: Kecerdasan Interpersonal

b. Predictors: (Constant), Model Cooperative Learning Tipe TGT

Keberartian $\mathrm{Y}$ atas $\mathrm{X}$ diperoleh signifikansi $0,049<\alpha=0,05$, maka dapat diaktakan regresi adalah linier. Dengan demikian persamaan regresi atas $Y=a+b X$ atau $Y=107,487+0,036 X$ dapat digunakan untuk memprediksi hubungan variabel $Y$ dengan menggunakan variabel $X$. Persamaan ini mengandung arti bahwa setiap kenaikan 1 satuan $\mathrm{X}$ akan diikuti dengan kenaikan $\mathrm{Y}$ sebesar 107,487 pada konstanta $0,036$.

Hubungan antara model pembe-lajaran cooperative learning tipe TGT dengan kecerdasan interpersoanl pada persamaan garis regresi $\mathrm{Y}=\mathrm{a}+\mathrm{bX}$ atau $\mathrm{Y}=107,487+0,036 \mathrm{X}$ dapat di-gambarkan dalam bentuk diagram sebagai berikut:

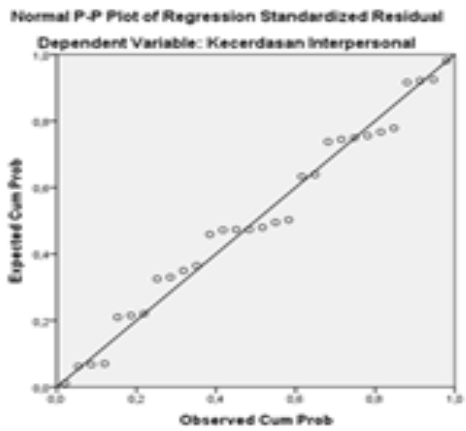

Gambar 3. Diagram Pencar Kecerdasan Interpersonal

Uji normalitas data dapat dilihat pada Tabel 6 dibawah ini.

Tabel 6. Uji Normalitas Y atas X

Normalitas Data Galat Taksiran

\section{Tests of Normality}

\begin{tabular}{lccccccc} 
& \multicolumn{6}{c}{ Kolmogorov-Smirnov a } & \multicolumn{4}{c}{ Shapiro-Wilk } \\
& Statistic & df & Sig. & Statistic & df & Sig. \\
\hline Kecerdasan Interpersonal & & & & & & \\
&, 139 & 30 &, 089 &, 975 & 30 &, 675
\end{tabular}

a. Lilliefors Significance Correction 
Dengan kriteria pengujian:

$\mathrm{H}_{\mathrm{o}}$ : Lhitung $<$ Ltabel (data berasal dari po

Populasi yang berdisribusi normal)

$\mathrm{H}_{1}$ : Lhitung $>\mathrm{L}_{\text {tabel }}$ (data berasal dari

populasi yang berdisribusi tidak normal)

Maka Lhitung $<\mathrm{L}_{\text {tabel }}$ atau Lhitung= 0,139

$<$ Ltabel $(\alpha 0,05 ; 30)=0,161$, artinya populasi berdistribusi normal

Karakteristik populasi dapat ber-variasi antara antara satu populasi dengan populasi yang lain. Maka untuk menge-tahui apakah varians skor yang diukur pada kedua sampel memiliki varians yang sama atau tidak digunakan uji homogenitas data dengan uji Bartlettt.

Berdasarkan atas tabel tersebut di atas, maka dapat dirangkum hasil uji homogenitas data dapat dilihat pada Tabel 7 sebagai berikut:

Tabel 7. Uji Homogenitas Data

\begin{tabular}{llll}
\hline \multicolumn{4}{c}{ Test of Homogeneity of Variances } \\
Kecerdasan Interpersonal \\
\hline Levene Statistic & df1 & df2 & Sig. \\
2,554 & 10 & 15 &, 049 \\
\hline
\end{tabular}

Dengan kriteria pengujian:

$\mathrm{H}_{\mathrm{o}}: \alpha^{2}$ hitung $<\alpha^{2}$ tabel (Populasi memiliki varians yang sama)

$\mathrm{H}_{1}: \alpha^{2}$ hitung $<\alpha^{2}$ tabel $(\mathrm{P}$ opulasi memiliki varians yang tidak sama)

Maka diperoleh : $\alpha^{2}$ hitung $<\alpha^{2}$ tabel $=$ $0,049<0,05$, maka populasi berasal dari varians yang sama.

Hasil pengolahan data dengan menggunakan Spss versi 23 untuk menguji pengaruh model pembelajaran Coo-perative Learning tipe Teams Games Tournament (TGT) terhadap Kecer-dasan Interpersonal pada Mata Pela-jaran IPS IV SD dtiunjukkan pada tabel 8 berikut.

Tabel 1 Korelasi Variabel Pembelajaran Cooperative Learning tipe Teams Games Tournament (TGT) Terhadap Kecerdasan Interpersonal

\begin{tabular}{|c|c|c|c|c|c|c|c|c|c|}
\hline \multicolumn{10}{|c|}{ Model Summary } \\
\hline \multirow{2}{*}{ Model } & \multirow{2}{*}{$\mathrm{R}$} & \multirow{2}{*}{ R Square } & \multirow{2}{*}{$\begin{array}{l}\text { Adjusted R } \\
\text { Square }\end{array}$} & \multirow{2}{*}{$\begin{array}{l}\text { Std. Error of } \\
\text { the Estimate }\end{array}$} & \multicolumn{5}{|c|}{ Change Statistics } \\
\hline & & & & & $\begin{array}{l}\text { R Square } \\
\text { Change }\end{array}$ & F Change & $\mathrm{df1}$ & $\mathrm{df} 2$ & Sig. F Change \\
\hline 1 & $.688^{\mathrm{a}}$ & .473 & 0.454 & 5,677 & .473 & 25,107 & & 28 & .000 \\
\hline
\end{tabular}

a.P redictors: (Constant), ModelCooperative Learning Tipe TGT

b. Dependent Variable: Kecerdasan Interpersonal

Tebel 9. Uji Signifikansi Korelasi Antara Variabel Model Pembelajaran Cooperative Learning Model TGT Terhadap Kecerdasan Interpersonal

Coefficients $^{\mathrm{a}}$

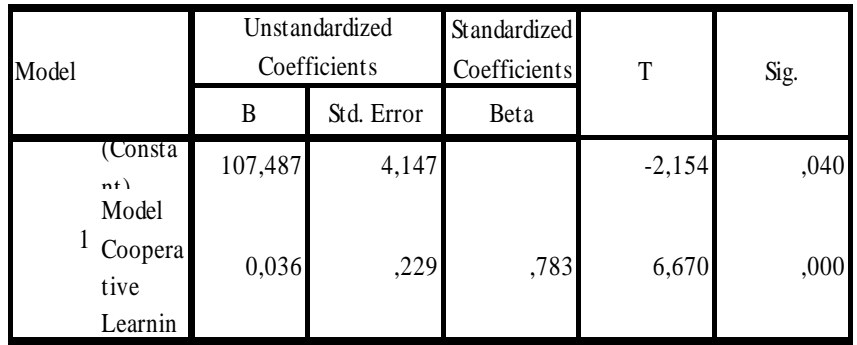

a. Dependent Variable: Kecerdasan Interpersonal 
Kekuatan hubungan model pem-belajaran cooperative learning tipe TGT dengan kecerdasan interpersonal ditun-jukkan dengan $r_{x y}=0,688$, yang berarti menunjukkan hubungan yang kuat. Uji keberartian koefisien korelasi dengan $t_{\text {hitung }}=6,670$. Harga tabel dengan $\mathrm{dk}=28$ dan taraf signifikansi $\alpha=$ 0,05 diperoleh nilai sebesar 2,048. dan pada $\alpha=0,01$ diperoleh nilai sebesar 2,763. Karena $t_{\text {hitung }}=6,670>$ $t_{\text {tabel }} \alpha=0,01$ sebesar 2,763 maka $\mathrm{H}_{\mathrm{o}}$ ditolak dan $\mathrm{H}_{1}$ diterima, berarti ada korelasi yang sangat signifikan antara model pem-belajaran cooperative learning tipe TGT dengan kecerdasan interpersonal. Sementara Koefisien determinasi $\left(\mathrm{R}^{2}\right)=\left(\mathrm{r}_{\mathrm{Xy}}\right)^{2}=0,473$, hal ini berarti bahwa varians pada Y kecer-dasan interpersonal dapat dijelaskan oleh varians model pembelajaran cooperative learning tipe TGT (X) sebesar 47,3\% dan sisanya sebesar 52,7\% dijelaskan oleh faktor-faktor lain yang tidak dikaji dalam penelitian ini. Hal ini juga berarti bahwa variabel model pembelajaran cooperative learning tipe TGT menjadi prediktor dari kecerdasan interpersonal.

Dari hasil pengujian hipotesis ini, maka dapat ditarik kesimpulan bahwa terdapat korelasi yang positif dan sangat signifikan model pembelajaran coo-perative learning terhadap kecerdasan interpersonal artinya semakin efektif langkah-langkah model pembelajaran cooperative learning tipe TGT di-lakukan maka akan semakin baik kecerdasan interpersonal. Hasil penelitian ini juga didukung oleh penelitian Muliantika (2017) menunjukkan bahwa terdapat perbedaan hasil belajar IPA antara kelompok siswa yang dibelajarkan dengan menggunakan model pembelajaran TGT dan kelompok siswa yang tidak dibelajarkan dengan menggunakan model pembelajaran TGT dengan perhitung thitung $=3,803>$ ttabel $=$ 2,021. Rata-rata skor hasil belajar IPA kelompok siswa yang dibelajarkan dengan menggunakan model pembelajaran TGT adalah 20 lebih tinggi dari pada kelompok siswa yang tidak dibelajarkan dengan menggunakan model pembelajaran TGT yaitu 16. Selain itu Fatmawati (2013) mengatakan rata-rata skor hasil belajar IPA kelompok yang dibelajarkan dengan model pembelajaran TGT menunjukkan hasil lebih tinggi dari pada model pembelajaran konvensional. Hasil penelitian ini menunjukkan bahwa terdapat pengaruh positif model pembelajaran TGT terhadap hasil belajar IPA pada siswa kelas V SD.

\section{Simpulan dan Saran}

Berdasarkan hasil penelitian dan pembahasan, diperoleh beberapa hasil antara lain: 1) pembelajaran Ilmu Pengetahuan Sosial (IPS) dengan model pem-belajaran Cooperative Learning tipe Teams Games Tournament (TGT) diberikan secara tepat kepada siswa maka dapat memberikan perubahan terhadap tumbuhnya kecerdasan interpersonal siswa, 2) Pembelajaran penggunaan cooperative learning tipe TGT berpengaruh untuk meningkatkan Kecerdasaan Interpersonal, 3) Hasil pengujian hipotesis diperoleh bahwa $\mathrm{t}_{\text {hitung }}$ lebih besar dari $\mathrm{t}_{\text {tabel }}$ pada $\alpha=0,01$ yaitu 2,763, maka $\mathrm{H}_{\mathrm{o}}$ ditolak dan $\mathrm{H}_{1}$ diterima, maka dikatakan skor kecerdasan inter-personal siswa yang mendapatkan pembelajaran melalui model Coo-perative Learning tipe Teams Games Tournament (TGT) lebih tinggi daripada siswa yang mendapatkan pembelajaran melalui mo-del pembelajaran konvensional.

Dengan demikian, dapat disimpul-kan bahwa penerapan model Coo-perative Learning tipe Teams Games Tournament (TGT) dapat mempe-ngaruhi kecerdasan interpersonal siswa khususnya siswa kelas V Sekolah Dasar di SDN Kebon Jeruk 11 pagi, Jakarta Barat.

Berdasarkan kesimpulan dari penelitian ini, dapat disarankan: 1) Bagi Guru: Mengoptimalkan pelaksanaan model pembelajaran Cooperative Learning tipe Teams Games Tournament (TGT) untuk meningkatkan kecerdasan interpersonal siswa khususnya pada mata pelajaran Ilmu Pengetahuan Sosial (IPS) serta menciptakan pembelajaran yang menantang, 2) Bagi Sekolah: Sekolah dapat mengelola dan memberdayakan sumber belajar terutama dan model-model pembelajaran dalam rangka menunjang proses belajar mengajar oleh guru terutama dalam pembelajaran Ilmu Pengetahuan Sosial (IPS), 3) Bagi Peneliti lain: Melakukan penelitian lebih lanjut mengenai pengaruh model pembelajaran Cooperative Learning tipe Teams Games Tournament (TGT) terhadap kecerdasan interpersonal pada mata pelajaran IPS kelas IV SD dan kaitannya dengan aspek-aspek lain

\section{Daftar Pustaka}

Abu Ahmadi, (2003) Ilmu Sosial Dasar (Jakarta: PT RINEKA CIPTA)

Adi W. Gunawan,(2011) Born to be a Genius (Jakarta: PT Gramedia Pustaka Utama)

Agus Suprijono, (2011) Cooperative Learning-Teori dan Aplikasi PAIKEM (Yogyakarta: Pustaka Pelajar) 
Chatib, Munif. (2015). Sekolahnya Manusia

Desmita,(2010) Psikologi Perkembagan (Bandung: Rosda)

Deddy Wahyudi, Pembelajaran IPS Berbasis Kecerdasan Interpersonal, Interpersonal dan Eksistensial http://jurnal.upi.edu/file/4-Deddy_Wahyudi.pdf. (Online)

Depdiknas, (2006) Kurikulum Tingkat Satuan Pendidikan SD/MI (Jakarta: Depdiknas)

Fakih Samlawi,dkk, Konsep Dasar IPS (Jakarta: Depdikbud)

Fatmawati. As., I Nym. Jampel, I Wyn. Widiana. 2013. Pengaruh Model Pembelajaran Tgt (Teams Games Tournament) Terhadap Hasil Belajar Ipa Pada Siswa Kelas V SD. E-journal Universitas Pendidikan Ganesha. Di d akses melalui ejournal.undiksha.ac.id/index.php/JJPGSD/article\%20/viewFile/1262/1125

Handini, Kecerdasan interpersonal pada siswa IV SDN kembaran kulon 1

Huda ,Miftahul. (2014). Model- Model Pengajaran dan Pembelajaran

Imanita, (2014). jurnal pendidikan Penga-ruh metode pembelajaran dan kecerdasan interpersonal terhadap hasil belajar sisa SMA

Isjoni,(2009) Cooperative Learning-Mengembangkan Kemampuan Belajar Berkelompok (Bandung: Alfabeta, 2007),dung: PT REMAJA ROSDAKARYA)

Jasmine, Julia. (2016). Metode Mengajar MULTIPLE INT

Jalaluddin Rakhmat, (2007) Psikologi Komunikasi (Bandung: Rosda) ELLIGENCES

Lou Russel,(2001) The Accelerated Learning Fieldbookditerjemahkan oleh M. Irfan Zakkie (Bandung: Nusa Media)

Muliantika, Pt. Frendita I Gd. Margunayasa, I Md. Citra Wibawa. 2017. Pengaruh Model Pembelajaran Tipe Teams Games Tournament (Tgt)Terhadap Hasil Belajar Ipa Siswa Kelas V SD. e-Journal PGSD Universitas Pendidikan Ganesha Mimbar PGSD Vol: 5 No: 2

Metode Pembelajaran IPS Terpadu-Analisis Kritis tentang Metode, Strategi, Evaluasi, dan Media Pembelajaran Bidang Studi Sejarah, Geografi, Ekonomi, Sosiologi, Antropologi dan Isu Pembelajaran IPS Terpadu (Jakarta: PT Prestasi Pustakaraya, 2011)

Model Pembelajaran IPS (Jakarta: Bumi Aksara)

Robert E. Slavin, (2009) Cooperative Learning (Theory, Research and Practice) (Boston: Allyn and Bacon)

Priansa, Doni Juni. (2014) . Kinerja dan Profesionalisme GURU. Bandung: CV Alfabeta.

Rusman,(2011) Model-Model Pembelajaran Mengembangkan Profesionalisme Guru (Jakarta: PT RAJAGRAFINDO PERSADA)

Rohmah, Emay Aenu, Wahyudin. 2016. Pengaruh Model Pembelajaran Kooperatif Tipe Teams Games Tournament (Tgt) Berbantuan Media Game Online Terhadap Pemahaman Konsep Dan Penalaran Matematis Siswa. EduHumaniora: Jurnal Pendidikan Dasar, ISSN 2085-1243 Vo. 8. No.2 Hal 126-143.

Said, Budimanjaya. (2015). 95 Strategi Mengajar Multiple Intelligences

Sapriya,(2008) Pendidikan IPS (BanEtin Solihatin, Raharjo, Cooperative Learning-Analisis 
Suyadi,(2009) Anak yang Menakjubkan (Yogyakarta: DIVA Press)

Thomas Armstrong,(2009) Multiple Intelligences in the Classroom (Alexandria: ASCD)

Trianto,(2010) Model Pembelajaran Terpadu -Konsep, Strategi, dan Implementasinya dalam Kurikulum Tingkat Satuan Pendidikan (Jakarta: Bumi Aksara)

T. Safaria,(2005) Interpersonal Intelligence-Metode Pengembangan Kecerdasan Interpersonal Anak (Yogyakarta: AMARA BOOKS)

Winataputra dkk,(2015) Pembaruan Dalam Pembelajaran.

Wahyuni dkk, JURNAL PESONA DASAR Universitas Syiah kuala vol 3. No 4, Oktober 2016, hal 33 42 Hubungan Kercerdasan Interpersonal Siswa Dengan Perilaku Verbal Bullying di SDN 40 Banda Aceh 